\title{
The Frequency of Hepatitis B Virus, Hepatitis C Virus and Human Immunodeficiency Virus Infections among Patients with Schizophrenia in a Mental Health Hospital in Turkey
}

\author{
Türkiye'de Bir Ruh Sağl|ğı Hastanesinde Șizofreni Hastalarında Hepatit B Virüs, Hepatit C Virüs \\ ve Insan Immün Yetmezlik Virüsü Sıklığı
}

\author{
Nuran KARABULUT
}

Mental Health Hospital Center Laboratory, Medical Microbiology Laboratory, Elazığ, Turkey

\begin{abstract}
Objective: Several studies have demonstrated that psychiatric patients are at increased risk for hepatitis B virus (HBV), hepatitis C virus (HCV) and human immunodeficiency virus (HIV) infections compared the general population. The aim of this study was to determine the frequency of HBV, HCV and HIV infections among patients with schizophrenia in Elazığ Mental Health Hospital in Turkey.

Materials and Methods: Screening tests for HBV, HCV and HIV have been routinely performed in patients with schizophrenia. Hepatitis B surface antigen (HBsAg), anti-hepatitis B surface (anti-HBs), anti-HCV and anti-HIV tests were performed by the ELISA technique.

Results: Four hundred and eighty-nine patients with schizophrenia in the mental health hospital were screened for HBsAg, anti-HBs, anti-HCV and anti-HIV. The study population was consisted of 409 male and 80 female patients. Overall seroprevalence was detected as $6.5 \%$ for $\mathrm{HBsAg}, 41.5 \%$ for anti-HBs and $0.2 \%$ for anti-HCV. All patients were found to be anti-HIV-negative.

Conclusion: This study showed that the frequency of HBV, HCV and HIV infections among patients with schizophrenia was no higher than in the general population. Screening for blood-borne pathogens at the time of admission to the hospital is an important strategy to identify infected residents. Furthermore, hepatitis $B$ vaccination schedule should be extended to include all the community.

Keywords: Hepatitis B, hepatitis C, human immunodeficiency virus, schizophrenia
\end{abstract}

ÖZ

Amaç: Birçok çalışma, genel popülasyon ile karşılaştırılığında psikiyatri hastalarının hepatit $B$ virüs $(\mathrm{HBV})$, hepatit $C$ virüs (HCV) ve insan immün yetmezlik virüsü (HIV) enfeksiyonları için artmış risk altında olduğunu göstermiştir. Bu çalışmanın amacı, Türkiye'de Elazığ Ruh Sağlığı ve Hastalıkları Hastanesi'nde şizofreni hastalarında HBV, HCV ve HiV enfeksiyon sıklığını belirlemekti.

Gereç ve Yöntemler: HBV, HCV ve HilV için tarama testleri, şizofreni hastalarında rutin olarak uygulanmıştır. Hepatit B'nin yüzey antijeni (HBsAg), anti hepatit B yüzey antikoru (anti-HBs), anti-HCV ve anti-HIV testleri, ELISA yöntemi ile çalışıldı.

Bulgular: Ruh sağlığı hastanesindeki dört yüz seksen dokuz şizofreni hastası, HBsAg, anti-HBs, anti-HCV ve anti-HIV için tarandı. Hasta popülasyonu, 409 erkek ve 80 kadın hastadan oluştu. Genel seroprevalans, HBsAg için \%6,5, anti-HBs için $\% 41,5$ ve anti-HCV için $\% 0,2$ olarak tespit edildi. Anti-HIV, tüm hastalarda negatif saptandl.

Sonuç: Bu çalışma, şizofreni hastalarında HBV, HCV and HiV enfeksiyon sıklı̆ıııın genel popülasyondan daha yüksek olmadığını göstermiştir. Hastaneye başvuru sırasında kan yoluyla bulaşan patojenler için tarama yapııması, enfekte bireyleri belirlemek için önemli bir stratejidir. Ayrıca, hepatit B aşılama programı tüm toplumu kapsayacak şekilde genişletilmelidir.

Anahtar Kelimeler: Hepatit B, hepatit C, insan immün yetmezlik virüs, şizofreni

Karabulut N. The Frequency of Hepatitis B Virus, Hepatitis C Virus and Human Immunodeficiency Virus Infections among Patients with Schizophrenia in a Mental Health Hospital in Turkey. Viral Hepat J 2016;22:48-51 


\section{Introduction}

Preventing and managing hepatitis B virus (HBV), hepatitis C virus $(\mathrm{HCV})$ and human immunodeficiency virus $(\mathrm{HIV})$ infections is a serious public health issue worldwide. Worldwide, 240 million people are chronically infected with $\mathrm{HBV}$, accounting for more than 620.000 deaths per year. $2.35 \%$ of the world population is chronically infected with $\mathrm{HCV}$, approximately 160 million people worldwide $(1,2)$. The estimated number of persons living with HIV in the world was approximately 36.9 million at the end of 2014 (3). The prevalence of HBV, HCV and HIV infections shows variations across different geographical areas in the world. Turkey is classified as a country of intermediate endemicity for $\mathrm{HBV}$ and $\mathrm{HCV}$ infections. According to the Turkish Ministry of Health, the first HIV case in Turkey was reported in 1985, and 11.109 HIV cases were reported until the end of March 2016 (4). A vaccine against hepatitis B has been available since 1982 (5), yet a systematic vaccination policy was not adopted at that time in Turkey. Since 1998, hepatitis $B$ vaccination has been included in the national immunization program (6).

In several studies, it has been reported that psychiatric patients have an increased risk for hepatitis B, hepatitis C and HIV infections compared the general population $(7,8)$. Comorbidity of schizophrenia and viral diseases incurs a worse prognosis for both conditions (9). Psychiatric symptoms may increase the risk of contracting blood-borne viral infections among people with severe mental illness including those with schizophrenia. Many patients with schizophrenia have high-risk sexual behavior and inadequate knowledge about protective measures or transmission or the risks of these diseases. To stay long periods in same-sex wards in hospitals may foster high-risk same-sex activity (10). In addition, due to the use of common shaving accessories in male patients may lead to parenteral transmission of these infections. These factors may increase the risk of transmission of blood-borne infections among psychiatric patients. Screening for and prevention of sexually-transmitted infections and blood-borne viruses are neglected in this population. Determining the frequency of HBV, $\mathrm{HCV}$ and HIV infections among patients with schizophrenia has a significant role in designing the strategies to control the disease. Data about the prevalence of these infections among patients with schizophrenia in Turkey could not be found in the literature. Therefore, this study was conducted to determine the frequency of HBV, HCV and HIV infections among patients with schizophrenia in Elazığ Mental Health Hospital, Turkey.

\section{Materials and Methods}

The mental health hospital is a state hospital with 488 beds in the Eastern Anatolia region of Turkey. The hospital serves 18 cities in Eastern and Southeastern Anatolia. Screening tests for HBV, HCV and HIV have been routinely performed in patients admitted to the psychiatry ward. This retrospective study included 489 patients with schizophrenia (409 males, 80 females) in Elazığ Mental Health Hospital in 2015. The study was approved by the Firat University Ethics Committee.

\section{Laboratory Examinations}

Blood samples were analyzed in the central clinical laboratory of the hospital. HBsAg, anti-HBs, anti-HCV (GBC, Taiwan, R.O.C.) and anti-HIV (DIA.PRO, Milano, Italy) tests were performed using the Triturus system (Grifols, Parets del Valles, Spain) by the ELISA method. The positive and negative controls were included each run. Specimens with a cutoff index of $<1$ were considered as nonreactive; cutoff index $\geq 1$ was considered as reactive for $\mathrm{HBsAg}$, anti-HCV and anti-HIV tests. Samples with below $10 \mathrm{mlU} / \mathrm{mL}$ were considered as non-reactive, and values of above $10 \mathrm{mlU} / \mathrm{mL}$ were considered as reactive for anti-HBs. Initially reactive assays were repeated in duplicate.

\section{Statistical Analysis}

Statistical analyses were performed using SSPS 20 (SPSS Inc, Chicago, IL, USA). The chi-square test was used for categorical comparisons of nominal values in different groups. The KruskalWallis test was used to compare parameters among the age groups. A $p$ value of less than 0.05 was considered statistically significant.

\begin{tabular}{|c|c|c|c|c|c|c|}
\hline \multirow[t]{2}{*}{ Characteristics } & & \multirow[b]{2}{*}{ Number of subjects } & \multicolumn{2}{|l|}{$\mathrm{HBsAg}$} & \multicolumn{2}{|l|}{ Anti-HBs } \\
\hline & & & Positive patients $\mathbf{n}(\%)$ & p & Positive patients n (\%) & p \\
\hline \multirow[t]{2}{*}{ Gender } & Male & 409 & $28(6.8)$ & 0.541 & $164(40.1)$ & 0.151 \\
\hline & Female & 80 & $4(5.0)$ & & $39(48.8)$ & \\
\hline \multirow{4}{*}{ Age groups } & $20-29$ & 59 & $3(5.1)$ & & $22(37.3)$ & \\
\hline & $30-39$ & 136 & $12(8.8)$ & & $37(27.2)$ & \\
\hline & $40-49$ & 146 & $7(4.8)$ & & $74(50.7)$ & \\
\hline & $50-59$ & 98 & $8(8.2)$ & & $42(42.9)$ & \\
\hline
\end{tabular}




\section{Results}

The mean age of 489 patients with schizophrenia was $42.46 \pm 11.29$ years (range: $15-74$ years).

As shown Table 1, 32 HBsAg-positive cases were reported, and the seroprevalence of HBsAg was determined as 6.5\%. There was no significant difference in the frequency of HBsAg between genders. Additionally, no significant difference was found in the seroprevalence rate of HBsAg between age groups.

203 patients were detected to be anti-HBs-positive, and the seroprevalence rate was $41.5 \%$. There was no significant difference in the seroprevalence rate of anti-HBs between genders. The highest seroprevalence was detected in the age group under 20 years $(p<0.001)$ (Table 1$)$.

The seroprevalence rate of Anti-HCV was $0.2 \%$. A 63-year-old male patient was detected to be anti-HCV-positive. In addition, antiHIV was negative in all the patients.

\section{Discussion}

Psychiatric patients do not have awareness about risk factors facilitating transmission of blood-borne viruses, and protective measures against these infections. Several studies have indicated that patients with mental illnesses are at an increased risk for $\mathrm{HBV}$, $\mathrm{HCV}$ and HIV infections. Although the prevalence of HBV, HCV and HIV in the general was found to be $4.9 \%, 1.8 \%$ and 0.32 $0.42 \%$ respectively, it was $23.4 \%, 19.6 \%$ and $5.2-22.9 \%$ among individuals with severe mental illness. The prevalence of bloodborne viral infections in people with serious mental illness has been found to be higher than in the general population in the U.S.A (11). A meta-analysis of studies of the prevalence of HIV, HBV and HCV in people with severe mental illness published between 1980 and 2015 found that the prevalence of blood-borne viral infections in people with serious mental illness was consistently higher than in the general population in regions with a low prevalence of bloodborne viruses, such as the USA and Europe, and on par with the general population in regions with high general prevalence such as Africa for HIV and Southeast Asia for HBV and HCV (12). A study conducted in patients with chronic schizophrenia in Taiwan revealed that the seroprevalence of HBsAg and anti-HCV was $10.4 \%$ and $1.9 \%$, respectively. The authors reported that this prevalence among patients with schizophrenia was not higher than in the general population in Taiwan (13).

The prevalence of HBV, HCV and HIV among 5.227 psychiatric patients in Elazığ Mental Health Hospital between 2011 and 2013 was reported in our previous study. According to this study, overall seroprevalence was $4.08 \%$ for $\mathrm{HBsAg}, 42.19 \%$ for anti-HBs and $0.69 \%$ for anti-HCV. HIV was not detected among the subjects of the study (14). In 2009, the seroprevalence of HBsAg, antiHBs and anti-HCV in 1343 patients in a psychiatric hospital in the western part of Turkey was detected as $2.7 \%, 30.5 \%$ and $1.8 \%$, respectively (15). The present study has demonstrated that the frequency of $\mathrm{HBsAg}$, anti-HBs and anti-HCV among patients with schizophrenia was $6.5 \%, 41.5 \%$ and $0.2 \%$, respectively. All the patients were anti-HIV-negative. The frequency of HBV infection among patients with schizophrenia was not higher than in the general population. Additionally, the prevalence of HCV and HIV in the general population in Turkey is already low. In our hospital, various preventive measures such as continuous surveillance, education of the psychiatric patients regarding transmission of blood-borne infections, and improving hospital conditions for patients are being taken.

The most dramatic decline in HBsAg positivity was observed among patients with schizophrenia under the age of 20 years. Anti-HBs positivity was detected in $80 \%$ of this group. In Turkey, hepatitis $B$ vaccination was included in the national immunization program in 1998, and infants have been vaccinated with three doses. Adults in the risk groups are also vaccinated at their request $(16,17)$.

This study has several limitations. The tests separating the active and chronic infection could not be analyzed. In addition, the test showing the evidence of previous HBV vaccination or past $\mathrm{HBV}$ infection in anti-HBs-positive patients could not be performed. Finally, it was a retrospective study, and risk factors associated with transmission of HBV and HCV in the patients could not be determined.

This study showed that the frequency of HBV, HCV and HIV infections among patients with schizophrenia was not higher than in the general population. Screening for blood-borne pathogens including HBV, HCV and HIV at the time of admission to the hospital is an important strategy to identify infected residents. Hepatitis B vaccination schedule should be extended to include all the community. Lastly, strategies targeting at risk reduction will be important to prevent further spread of blood-borne infections among psychiatric populations.

\section{Ethics}

Ethics Committee Approval: This retrospective study included 489 patients with schizophrenia (409 males, 80 females) in Elazığ Mental Health Hospital in 2015. The study was approved by the Firat University Ethics Committee.

Peer-review: External and Internal peer-reviewed.

\section{References}

1. Inan N, Tabak F. Hepatitis B Virus: Biology and Life Cycle. Viral Hepatitis Journal 2015;21:1-7.

2. Özdemir M, Altındiş M. Improvement and New Aspects of HCV Testing for Clinical Management. Viral Hepatitis Journal 2013;19:93-98.

3. WHO. HIV/AIDS. [15.02.2016]; Available from: http://www.who. int/mediacentre/factsheets/fs360/en/.

4. TC Sağlık Bakanlığı. 1 Aralik Dünya Aids Günü. [09.03.2016]; Available from: http://www.saglik.gov.tr/TR/belge/1-44461/ basin-aciklamasi.html.

5. Tosun S. Hepatitis B Virus Vaccine. Viral Hepatitis Journal 2012;18:37-46.

6. Ay P, Torunoglu MA, Com S, Çipil Z, Mollahaliloğlu S, Erkoc Y, Dilmen U. Trends of hepatitis B notification rates in Turkey, 1990 to 2012. Euro Surveill 2013;18:20636. 
7. Essock SM, Dowden S, Constantine NT, Katz L, Swartz MS, Meador KG, Osher FC, Rosenberg SD, Five-Site Health and Risk Study Research Committee. Risk factors for HIV, hepatitis $\mathrm{B}$, and hepatitis $\mathrm{C}$ among persons with severe mental illness. Psychiatr Serv 2003;54:836-841.

8. Alvarado Esquivel $C$, Arreola Valenzuela MA, Mercado Suárez MF, Espinoza Andrade F. Hepatitis B virus infection among inpatients of a psychiatric hospital of Mexico. Clin Pract Epidemiol Ment Health 2005;1:10.

9. Cournos F, McKinnon K, Sullivan G. Schizophrenia and comorbid human immunodeficiency virus or hepatitis C virus. J Clin Psychiatry 2005;66(Suppl 6):27-33.

10. Wainberg ML, Cournos F, McKinnon K, Berkman A, Guimaraes MDC. HIV and hepatitis $C$ in patients with schizophrenia. In: Meyer JM, Nasrallah HA (eds). Medical Illness and Schizophrenia. Second ed. Arlington, VA: American Psychiatric Publishing; 2009;247-275.

11. Rosenberg SD, Swanson JW, Wolford GL, Osher FC, Swartz MS, Essock SM, Butterfield MI, Marsh BJ, Five-Site Health and Risk Study Research Committee. The five-site health and risk study of blood-borne infections among persons with severe mental illness. Psychiatr Serv 2003;54:827-835.
12. Hughes E, Bassi S, Gilbody S, Bland M, Martin F. revalence of HIV, hepatitis $B$, and hepatitis $C$ in people with severe mental illness: a systematic review and meta-analysis. Lancet Psychiatry 2016;3:40-48.

13. Hung CC, Loh el-W, Hu TM, Chiu HJ, Hsieh HC, Chan CH, Lan $\mathrm{TH}$. Prevalence of hepatitis $\mathrm{B}$ and hepatitis $\mathrm{C}$ in patients with chronic schizophrenia living in institutions. J Chin Med Assoc 2012;75:275-280.

14. Karabulut N. Prevalence of HBV, HCV and HIV in Inpatients of a Mental Health Hospital in Turkey, 2011-2013. Iran J Public Health 2015;44:1026-1028.

15. Sezak N, Tosun S, Eris N, Ayer A. Prevalence of Hepatitis $B$ and Hepatitis C Infections and Evaluation of Related Factors in Patients in a Mental Health Hospital. Klimik Journal 2012;24:154-157.

16. Altay T, Uskun E, Akcam FZ. Seroprevalence of hepatitis B surface antigen and its correlation with risk factors among new recruits in Turkey. Braz J Infect Dis 2012;16:339-344.

17. Toy $M$, Önder FO, Wörmann T, Bozdayi AM, Schalm SW, Borsboom GJ, van Rosmalen J, Richardus JH, Yurdaydin C. Age-and region-specific hepatitis B prevalence in Turkey estimated using generalized linear mixed models: a systematic review. BMC Infect Dis 2011;11:337. 